\title{
Cattle Losses, Tall Larkspur, and Their
}

\section{Control}

\section{E. H. CRONIN, D. B. NIELSEN, AND NED MADSON}

Highlight: Correlation analyses of records of cattle poisoned by tall larkspur (Delphinium barbeyi Huth.) on three similar and adjacent cattle allotments on the Wasatch Platean produced low $\mathrm{r}^{2}$, indicating that losses are not related to annual fluctuations in environmental conditions or other factors shared by all three allotments. Control of the large, dense patches of tall larkspur with herbicides in one 2,000 acre subalpine pasture on the Manti Canyon Cattle Allotment dramatically reduced cattle losses. Small patches and scattered plants, which are difficult to locate and laborious to treat, apparently contribute very little to cattle losses. Examination of ruminal contents of calves found dead in the subalpine pasture in a 2-year period revealed large quantities of tall larkspur. None of the calves were orphans. All evidence suggests that the calves dying in the subalpine pastures were poisoned by tall larkspur. While mature cattle ingest lethal levels of tall larkspur in the large, dense patches, calves are apparently intoxicated by ingesting tall larkspur growing in small patches in the groves of trees scattered over the subalpine grazing units.

Previously, our researches have been directed toward development of effective herbicide treatments for controlling tall larkspur (Delphinium barbeyi Huth.) (Cronin, 1971; Cronin and Nielsen, 1972; and Cronin, 1974) and measurements of the impact of these treatments on the plant community (Cronin, 1976). However, the ultimate measurement of the effectiveness of herbicide treatments can only be measured in terms of livestock losses.

Applications of herbicides become inceasingly laborious and expensive as remaining tall larkspur patches are smaller, more widely scattered, and contain fewer plants per unit area. Eventually, more time is expended in travelling between sites than in treating plants; ultimately, locating isolated plants utilizes almost all the control effort. However, our observations indicate that larkspur becomes less dangerous to grazing cattle as it becomes more widely dispersed. Most cattle losses appear to be associated with large, dense patches of larkspur growing on late-melting snowdrift sites (Cronin, 1971).

The objective of this study was to determine if control of large, dense patches of larkspur would reduce cattle losses. To

Authors are plant physiologist, Poisonous Plant Research Laboratory, Idaho-MontanaUtah Area, Western Region, Agricultural Research Service, U.S. Department of Agriculture, Logan, Utah 84322; professor, Department of Economics, Utah State University, Logan 84322; and president, Manti Canyon Cattlemen's Association, Manti. Utah 84642.

The report involved cooperative investigations by Idaho-Montana-Utah Area, Western Region. Agr. Res. Serv., U.S. Dep. Agr., and Iftah Agricultural Experiment Station, Logan, Utah 84322. Utah Agricultural Experiment Station Paper No. 2007.

This is a report on the current status of research involving use of certain chemicals that require registration under the Federal Insecticide, Fungicide, and Rodenticide Act. It does not contain recommendations for the use of such chemicals, nor does it imply that the uses discussed have been registered. All uses of these chemicals must be registered by the appropriate State and Federal agencies before they can be recommended.

Manuscript received October 10, 1975. achieve this objective, it was necessary to make an assessment of deaths due to tall larkspur poisoning of cattle in the treated pasture as well as the other subalpine pastures of the Manti Canyon Cattle Allotment. In attempting to verify tall larkspur poisoning deaths, we made some observations not previously reported.

\section{Materials and Methods}

Records of losses for Manti Canyon Cattle Allotment were obtained from the District Forest Service Office and from the Manti Canyon Cattleman's Association. Since 1969, the records have included date of death, age, breed, ownership, and location of each animal. The rumen contents of many animals were examined within 18 hours of death for the presence of nodes of tall larkspur plants. Tracks of dead animals were often followed back to grazed tall larkspur plants.

Records of losses for two other allotments south of Manti Canyon were also obtained from the Forest Service. Six Mile Canyon Cattle Allotment is about equal in area and carrying capacity to Manti Canyon. Twelve Mile Canyon Cattle Allotment on the south is the largest of the three allotmets and has the greatest carrying capacity.

North Fork Grazing Unit was selected for measuring the effects of controlling tall larkspur on cattle losses because relatively higher losses have consistently occurred on this unit. The 2,000 acre unit includes the subalpine portions of the North Fork and Jollys Hole drainages of Manti Canyon. Evaluation of the effects of controlling tall larkspur in the North Fork Grazing Unit of Manti Canyon was accomplished by comparing losses on the treated grazing unit to losses on the remaining subalpine grazing units of Manti Canyon. The expected loss ratio was established from records of losses on the allotment from 1956 through 1969.

Control treatments consisted of two to three repeated applications of $2,4,5-\mathrm{T}$ [ (2,4,5-trichlorophenoxy)acetic acid] at $4 \mathrm{lb} /$ acre (Cronin and Nielsen, 1971; and Cronin, 1972). Only two applications were normally required to control the tall larkspur but on a few sites three treatments were needed. Treatments were applied by various methods including mist blowers, boomless sprayers, and by hand sprayers attached to a pump on a truck.

Herbicide treatments began in 1969 , but no treatments were applied in 1970. By August of 1972 all but two of the large, dense patches of larkspur had been treated at least once. No treatments were applied in the North Fork unit in 1973 but applications in 1974 completed the treatment regime for most of the patches scheduled for control.

Grazing activities were observed during 1971 through 1974. Observations were made from first light to dusk for the first 2 weeks after cattle were turned into the subalpine grazing units each year. Most of the observations were made with binoculars and a spotting scope. Blinds near selected large patches of tall larkspur were sometimes used for close observations.

Individual cows were observed with the spotting scope while grazing a patch of tall larkspur to identify species being grazed. When the animal moved away from the patch, the vegetation was examined 
to verify identification of the plants grazed. Animals grazing in these patches were also observed for signs of larkspur poisoning.

Twice each day, once in the morning between 9 and $11 \mathrm{a} . \mathrm{m}$., and once in the afternoon between 4 and 6 p.m., the grazing area was toured to locate dead animals. Dead cattle were examined for gross signs of poisoning such as bloating, position of the body on the slope, and evidence of struggling to stand before death. Rumen contents were then examined to identify plant species whenever possible. Nodes of tall larkspur ingested shortly before death occurs are easily identified for a week or more after death. It was assumed that the digestive process would alter the nodes beyond recognition with a few hours of ingestion. Beginning in 1972, the rumina of dead calves were also examined for evidence of tall larkspur ingestion.

Because there was concern that the herbicide might contaminate Manti Creek, the U.S. Forest Service requested the Utah State Division of Health to monitor the streams one-half to one mile below the sprayed areas for 2,4,5-T. The Division of Health agreed and had the streams below the sprayed area sampled in 1972 when 60 acres of the North Fork Unit were treated and again in 1973 when 50 acres were sprayed in the South Fork-Hougaard Fork Grazing Unit. In 1972, they received three pre-spray water samples but only one post-spray sample for analyses. In 1973, they received and analyzed two pre-spray and nine post-spray samples. The post-spray samples were obtained at intervals of from 1 to 72 hours after applications of the herbicide treatments. ${ }^{1}$

\section{Results and Discussion}

Treated plants may increase in palatability immediately following applications of herbicides. The total alkaloid content of tall larkspur increases following applications of 2,4,5-T or silvex [2-(2,4,5-trichlorophenoxy) propionic acid] (Williams and Cronin, 1963). Therefore, any increased use of tall larkspur would probably increase losses and cattle should not be permitted to graze treated areas until the aerial portions of tall larkspur are dead and dried.

Tabulation of cattle losses on the Manti Canyon, Six Mile Canyon, and Twelve Mile Canyon allotments reveals large annual variations in losses over the 14-year period (Table 1). Analyses of these data also show very low correlations between annual losses on the three allotments. The $r^{2}$ for Manti and Six Mile Canyon allotments is 0.36, between Manti Canyon and Twelve Mile Canyon it is 0.24, and between Six and Twelve Mile Allotments the $r^{2}$ is only 0.21 .

It is generally accepted that the toxicity of tall larkspur varies between years. The annual variation in total alkaloid content has been documented (Williams and Cronin, 1963). However, if losses were solely dependent on annual variations in toxicity or total alkaloid content of tall larkspur, it would be logical to assume that a high correlation would exist between the adjacent allotments. Further, low correlations obtained from our data suggest that weather, snow pack, total aerial cover of the vegetation, apparent degree of use of the grasses, and other shared factors do not strongly influence losses on these three adjacent allotments.

Therefore, the number of poisonings must be correlated with factors varying within an allotment, as for example, the grazing management. Our observations tend to implicate a relationship between grass maturity and tall bluebell (Mertensia arizonica Greene) palatability as contributing to losses. The cattle appear to change abruptly from a grass diet to a diet high in forbs without regard to the degree of use or availability of grass

'Pesticide analyses were performed pursuant to contract $68-02-0571$ between the Environmental Protection Agency and the Utah State Department of Social Services Division of Health under the direction of Dr. J. W. Southwick.
Table 1. Percent of cattle on the allotment killed each year and whose death was attributed to tall larkspur poisoning, for three adjacent cattle allotments on the Wasatch Plateau.

\begin{tabular}{cccc}
\hline & \multicolumn{3}{c}{ Allotment } \\
\cline { 2 - 4 } Year & $\begin{array}{c}\text { Manti } \\
\text { Canyon }^{1} \\
(\%)\end{array}$ & $\begin{array}{c}\text { Six Mile } \\
\text { Canyon }^{2} \\
(\%)\end{array}$ & $\begin{array}{c}\text { Twelve Mile } \\
\text { Canyon }^{3}{ }^{6}\end{array}$ \\
\hline 1955 & - & - & 0.7 \\
1956 & 6.3 & 1.1 & 0.3 \\
1957 & 6.9 & - & - \\
1958 & 12.3 & 6.9 & 2.0 \\
1959 & 5.4 & 1.3 & 0.9 \\
1960 & 2.3 & 0.9 & 1.5 \\
1961 & 2.0 & 1.9 & 0.5 \\
1962 & 4.4 & 2.0 & 1.0 \\
1963 & 1.5 & 0.9 & 0.2 \\
1964 & 1.5 & 1.4 & 0.7 \\
1965 & 2.3 & 1.4 & 0.7 \\
1966 & 2.1 & 3.2 & 1.0 \\
1967 & 2.6 & 4.6 & 0.4 \\
1968 & 6.8 & 2.7 & 2.0 \\
1969 & 3.8 & 2.0 & 1.7 \\
1970 & 4.0 & 3.7 & 1.7 \\
Average & 4.3 & 2.4 & 1.02 \\
\hline
\end{tabular}

${ }^{1}$ Manti Canyon Allotment contains 20,000 acres with an annual carrying capacity of about 4,225 AUM's.

${ }^{2}$ Six Mile Canyon Allotment contains 17,000 acres with an annual carrying capacity of about 3,750 AUM's.

${ }^{3}$ Twelve Mile Canyon Allotment contains 40,000 acres with an annual carrying capacity of about 8,420 AUM's.

${ }^{4} r^{2}$ (Manti Canyon vs Six Mile Canyon) $=0.36$.

${ }^{5} \mathrm{r}^{2}$ (Manti Canyon vs Twelve Mile Canyon) $=0.24$

${ }^{6} \mathbf{r}^{2}$ (Six Mile Canyon vs Twelve Mile Canyon) $=0.21$.

forage. When the change in grazing preference occurs, they apparently seek out the tall bluebell growing on the snowdrift sites in association with tall larkspur. Losses commence each summer as the cattle deplete the tall bluebell or find it unpalatable due to the development of powdery mildew on the leaves. The relationship between changing grazing preferences of cattle and larkspur poisoning appears to warrant further investigation by animal behavioral scientists.

The correlation analyses also emphasize the fallacy of using losses on one allotment to predict losses on another allotment even when they are similar in topography, vegetation, and weather.

On the other hand, when losses in the North Fork Grazing Unit (on the Manti Canyon Allotment) are compared with losses in the other subalpine grazing units of the allotment, correlation analyses revealed an $r^{2}$ of 0.98 (Table 2). Data for 1968 were not included in these analyses because a change in grazing regimen was imposed that year. (In 1968, cattle were turned into the North Fork Unit before they grazed the other subalpine units. When 1968 is included in the correlation analyses, the $r^{2}$ drops to 0.56.$)$

Loss records in Table 2 also permit comparison of early season losses to late season losses in the subalpine zone of Manti Canyon. Early season losses from 1956 through 1970, including 1968 , have consistently been twice the late season losses. The high correlation $\left(r^{2}=0.98\right)$ of the data in Table 2 (an early grazing period versus a late grazing period) justifies the use of data on losses in one area to predict losses in another area of the subalpine zone of Manti Canyon as long as the period of use is known and considered in the prediction.

Control of tall larkspur in the North Fork Grazing Unit has progressed slowly. Administrative restriction on the use of 2,4,5-T, lack of money for herbicides, and the unavailability of 
Table 2. A record of the yearly losses of mature cattle attributed to tall larkspur poisoning on the Manti Canyon Cattle Allotment from 1956 through 1970.

\begin{tabular}{lccc}
\hline \hline Year & $\begin{array}{c}\text { North Fork } \\
\text { Grazing Unit } \\
\text { (number) }\end{array}$ & $\begin{array}{c}\text { All other upper } \\
\text { subdivision } \\
\text { grazing units } \\
\text { (number) }\end{array}$ & $\begin{array}{c}\text { Total } \\
\text { (number) }\end{array}$ \\
\hline 1956 & $18^{1}$ & 35 & 53 \\
1957 & $19^{1}$ & 39 & 58 \\
1958 & $34^{1}$ & 69 & 103 \\
1959 & $15^{1}$ & 30 & 45 \\
1960 & $6^{1}$ & 13 & 19 \\
1961 & $6^{1}$ & 11 & 17 \\
1962 & $12^{1}$ & 25 & 37 \\
1963 & $5^{1}$ & 8 & 13 \\
1964 & $4^{1}$ & 9 & 13 \\
1965 & $6^{1}$ & 13 & 19 \\
1966 & $5^{1}$ & 13 & 22 \\
1967 & $8^{1}$ & 14 & 57 \\
1968 & $36^{2}$ & 21 & 32 \\
1969 & $11^{1}$ & 21 & 34 \\
1970 & $9^{1}$ & 346 & 540 \\
Total & 194 & 23 & 36 \\
Average & 13 & &
\end{tabular}

${ }^{1}$ Grazed during September.

${ }^{2}$ Grazed during the period July 15 to August 10 .

suitable equipment for applying herbicides to this steep, rough terrain have all contributed to prolonging the process. By 1975, approximately 63 acres had received two or more applications of herbicides (Fig. 1). The potential for future cattle poisoning can be further reduced by a second application to 3 large patches of tall larkspur. This represents about $60 \%$ of the acreage infested with tall larkspur in the North Fork Grazing Unit.

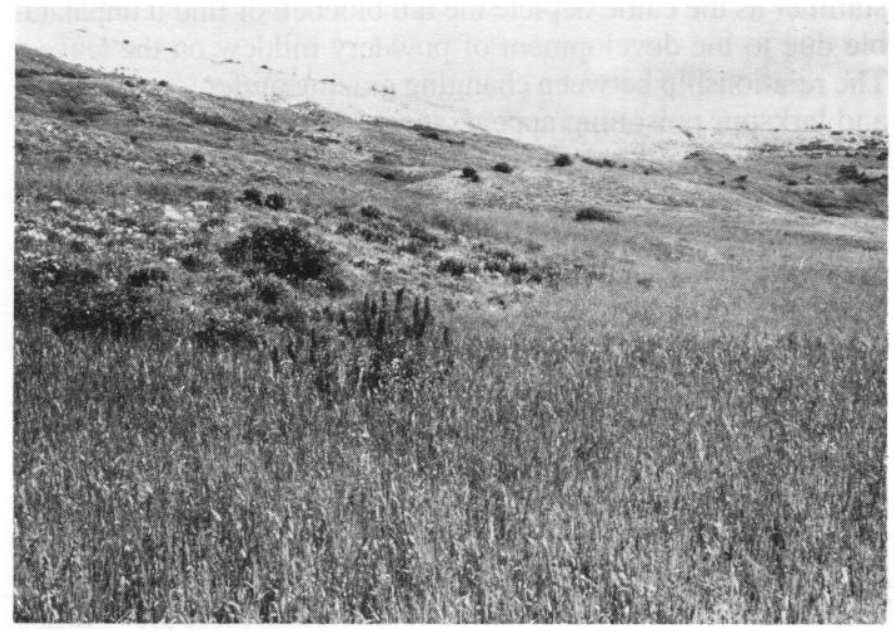

Fig. 1. Two applications of 2,4,5-T at $4 \mathrm{lb} /$ acre, one application in 1969 and one in 1971, combined with late season grazing converted a tall-forb community dominated by tall larkspur to this grass community dominated by mountain brome. Only one tall larkspur plant (left center foreground) remained on this site in 1974.

The effects of tall larkspur control on cattle losses have been even more dramatic than indicated by the data in Table 3 . Since the first treatments were applied on the west side of Jollys Hole in 1969, no mature cattle have died in this area. Further, since 1971, no mature cattle have been poisoned in the North Fork Grazing Unit, except for 3 cows in 1972 (Table 3). This was the first year this unit had been grazed at the first of the subalpine grazing season since 1968, when the cattle were moved from the
Table 3. Cattle losses from 1971 through 1975 in the North Fork Grazing Unit as compared with predicted losses that could have been expected without control of the larkspur.

\begin{tabular}{|c|c|c|c|}
\hline \multirow[b]{3}{*}{ Year } & \multirow{3}{*}{$\begin{array}{l}\text { Total losses } \\
\text { recorded in } \\
\text { Manti Canyon } \\
\text { Allotment } \\
\text { (numbers) }\end{array}$} & \multicolumn{2}{|c|}{ North Fork Grazing Unit ${ }^{1}$} \\
\hline & & Cattle losses with unit & \multirow[b]{2}{*}{$\begin{array}{l}\text { Grazing period } \\
\text { in unit }\end{array}$} \\
\hline & & $\begin{array}{cc}\begin{array}{c}\text { Actual } \\
\text { losses }\end{array} & \begin{array}{c}\text { Predicted } \\
\text { losses }\end{array} \\
\text { (numbers) } & \text { (numbers) }\end{array}$ & \\
\hline 971 & 14 & 7 & \\
\hline & & & \\
\hline & 3 & 1 & \\
\hline & $6^{4}$ & 3 & \\
\hline 975 & 32 & 16 & Dct. 1 \\
\hline \multicolumn{4}{|c|}{$\begin{array}{l}{ }^{1} \text { The tall larkspur control program was initiated in the North Fork } \\
\text { Grazing Unit in } 1969 \text { with small areas of the unit being treated each } \\
\text { year. } \\
{ }^{2} \text { The predicted losses are based on losses that occurred on the } \\
\text { remaining subalpine grazing units in each of the } 5 \text { years, and where tall } \\
\text { larkspur had not been controlled. } \\
{ }^{3} \text { After these two cattle were poisoned, the herd was moved into the } \\
\text { North Fork-Jollys Hole Grazing Unit to prevent further losses. } \\
{ }^{4} \text { Some patches of tall larkspur in the South Fork-Hougaard Fork } \\
\text { Grazing Unit were treated in } 1973 \text { which probably reduced losses for } \\
1974 \text {. }\end{array}$} \\
\hline
\end{tabular}

unit after only 3 weeks' grazing because 36 cows had died. Based on losses sustained on the remaining subalpine units, we have estimated the 1972 losses at 25 head rather than 3 cows, had most of the large patches of tall larkspur not been controlled in the North Fork Unit. Had the tall larkspur not been controlled, it is estimated that more than 49 head in addition to the 3 cattle that were poisoned would have died from 1971 through 1975. However, patches of plants recognized as potentially dangerous still exist on the east side of the unit. Unless these patches are controlled, future losses are likely to occur.

Rumina of 11 cows were examined from 1971 through 1973. All but one of these animals ingested very large amounts of tall larkspur prior to death. Each of the animals that had ingested larkspur became severely bloated before body heat was lost and before knee joints became stiff. If these signs are indeed indicative of tall larkspur poisoning, our experience indicates deaths due to causes other than tall larkspur poisoning in the subalpine zone are infrequent because almost all of the dead animals observed over the past 12 years exhibit these signs. These cows ranged in age from yearlings to cows at least 6 years old as determined by ear tags.

Calf losses in the subalpine zone have usually been attributed to the death of the mother because the calves were still nursing 3 to 4 times a day when the mother died. However, they also ingest substantial amounts of vegetation while nursing (Dwyer, 1961). Rumen contents of six calves that died near the first of August (four in 1972 and two in 1973) were examined. The presence of tall larkspur in their rumina, the rapidity of bloating following death, and observations of their grazing patterns indicate that all six were poisoned by tall larkspur. Five of the six calves had been grazing small patches of tall larkspur associated with groves of conifer trees. The calves typically remain in these groves while their mothers graze. Calves display little selective grazing behavior as it appears to be a learned process, and because of their small size, they can easily ingest enough larkspur to cause death.

Although the number of water samples analyzed was low, the results indicate that applications of 2,4,5-T for controlling tall larkspur can be done without contaminating the streams. In 1962, the Environmental Protection Agency established the maximum acceptable level of 2,4,5-T in culinary water at 2.0 
$\mathrm{ppb}$. The highest concentration found in the streams below the sprayed areas was $1.62 \mathrm{ppb}$. (Water from Manti Creek is not used for culinary purposes except perhaps by campers.)

\section{Summary and Conclusions}

No significant correlation exists for cattle losses due to tall larkspur poisoning among three similar and adjacent grazing allotments. The lack of correlation suggests that factors common to all three allotments such as temperature, precipitation, total alkaloid concentrations in tall larkspur or phenological development of the vegetation have little influence on cattle losses. Therefore, losses must depend on factors which vary within each allotment, such as grazing management.

Within the Manti Canyon Allotment, twice as many losses occurred in the subalpine unit grazed first as in the grazing unit used for late grazing. An $r^{2}$ of 0.98 confirms the consistency of this ratio over a 14-year period.

Cattle losses in one 2,000 -acre subalpine grazing unit were controlled by treating about $60 \%$ of the area infested with tall larkspur (approximately $3.2 \%$ of the area in the grazing unit) with applications of $2,4,5-\mathrm{T}$. Without control of the large, dense patches it is estimated that 49 or more additional cattle would have died in the period of 1971-1975.

Calves are poisoned by ingestion of tall larkspur. Like the mature animals, calves typically appear to ingest amounts far in excess of a lethal level. However, the infested sites where mature cattle and calves ingest lethal amounts of tall larkspur are not the same. Cattle typically are poisoned while grazing large, dense patches, while calves are poisoned by grazing the smaller patches associated with small groves of trees.

\section{Literature Cited}

Cronin, E. H. 1971. Tall larkspur: Some reasons for its continuing preeminence as a poisonous plant. J. Range Manage. 24:258-263.

Cronin, E. H., and D. B. Nielsen. 1972. Controlling tall larkspur on snowdrift areas in the subalpine zone. J. Range Manage. 25:213-216.

Cronin, E. H. 1974. Evaluations of some herbicide treatments for controlling tall larkspur. J. Range Manage. 27:219-222.

Cronin, E. H. The impact on associated vegetation of controlling tall larkspur. J. Range Manage. Accepted - in press.

Dwyer, D. D. 1961. Activities and grazing preferences of cows and calves in northern Osage County, Oklahoma. Okla. Agr. Exp. Sta. Bull. B-588. 61 p.

Williams, M. C., and E. H. Cronon. 1963. Effect of silvex and 2,4,5-T on alkaloid content of tall larkspur. Weeds 11:317-319. 